\section{THE NEW ERUPTION FROM HEKLA}

\section{BY DR. G. W. TYRRELL University of Glasgow}

$\mathrm{A}^{\mathrm{r}}$ FTER a hundred and two years of quiescence, Hekla broke out in violent eruption at about 6.50 a.m. on March 29, 1947. Three days later, Dr. Joh. Askelsson, of the High School of Reykjavik (University of Iceland), sent me a fragment of the new lava, which I described in a 'letter' in Nature (May 10, 1947). The lava proved to be identical with previous Hekla lavas and, indeed, with the general run of Recent lavas in southern Iceland. I got into touch with Dr. Trausti Einarsson, also of the University of Iceland, who, as well as Dr. Åskelsson, had been a research student in the Geological Department of the University of Glasgow. Dr. Einarsson sent me numerous newspaper cuttings (in Icelandic), two long letters descriptive of the eruption, and a new book, "Hekla", by Gudhb. Kjartansson (167 pp., with numerous illustrations and a map), which was published as a Yearbook of the Icelandic Touring Association, 1945. What follows is mainly derived from Dr. Einarsson's letters.

Numerous observers have been following the eruption, and relays of workers have made it possible to record its phenomena hour by hour. In addition to J. Askelsson and T. Einarsson, G. Kjartansson (author of the above-mentioned book), S. Thorarinsson, P. Hannesson, T. Tryggvasson and S. Sigurdsson among Icelandic geologists, N. Nielsen and A. NoeNygaard from Denmark, A. Gavelin from Sweden, and L. Hawkes of Bedford College, London, have visited Hekla and have worked on various aspects of the eruption. Samples of rocks and gases are being analysed in the State Research Laboratory, and some geophysical work is being done. Kjartansson and Tryggvasson will collaborate in a petrological and chemical study of all Hekla lavas.

According to Einarsson (letter of May 26), the main events of the eruption were as follows. It began a little before 6.50 a.m. on March 29, apparently without any preliminary symptoms. A considerable earthquake shock was felt as far away as Reykjavik; but, curiously enough, few noticed it in the region immediately surrounding the volcano, and people in

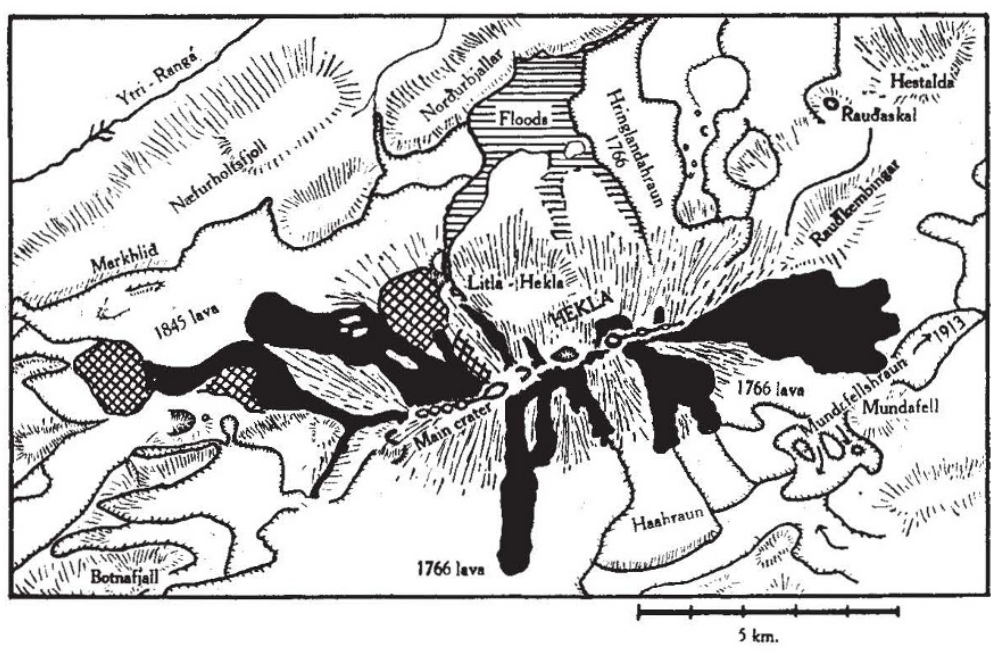

Fig. 1

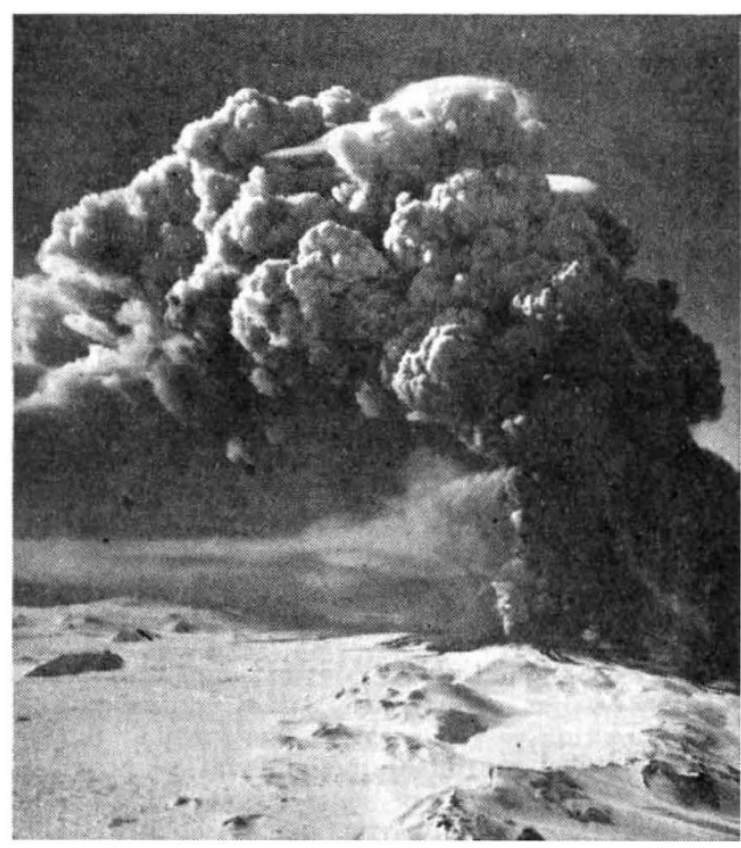

Fig. 2. HeKLA, MORNING OF MARCH 29, 1947, LOOKING SOUTHSOUTH-WEST. PHOTO BY V. SIQURGRIRSSON, REYKJAVLK

farms only $9 \mathrm{~km}$. distant were not even awakened. No serious damage was done by this shock. The sky was clear and, immediately after the shock, an enormous column (of steam and ash ?), more than $20 \mathrm{~km}$. in height, was seen from Reykjavik. A north wind was blowing which carried the erupted material southward. The inhabited regions of Fljòtshlidh and Eyjafjöll were enveloped in complete darkness and soon covered by a layer of pumice and ash three inches thick. A continuous wall of black 'smoke' $10 \mathrm{~km}$. high extended far out to sea.

At 10 a.m. Einarsson and others took aeroplane to the scene and found black clouds of ash being whirled out with tremendous force from a number of craters along the whole length of the volcano. (Hekla is an elongated ridge rather than a cone; see map, Fig. 1.) The mountain itself seemed a trifle in comparison with the enormous columns of ash (see Fig. 2). Lava had even then reached the plateau surface to the north and east of Hekla, and it was ascertained later that the lava was actually issuing from the whole length of the ridge. Streams of black mud were also being generated, no doubt by the mixture of thawed glacier ice and snow with ash ; and on the first morning of the eruption an enormous rush of water from the north-west slope of the volcano caused a flood in the River Ytri-Rangà-a common feature of previous eruptions (see map).

Einarsson measured the temperature $\left(950^{\circ} \mathrm{C}\right.$.) of a lava flow from a low-level crater on the southwestern flank near Nafrholt. The lava here is welling out quietly as a fountain, and is very viseous. "With good asbestos insulation", says Einarsson, "it would be a simple matter to walk on it in the crater 
itself. You can stand on the rim in the crater and reach the lava with a stick."

At the same time furious explosions were taking place in the higher craters. In a few days, however, the activity greatly diminished, especially at the northern end of the ridge. Lava ceased to flow from the crest, but flowed continuously, and still flows, from the low south-western craters. The extent of the new lavas on April 8 is shown on the map (in solid black).

While all activity ceased in the north-east and lava ceased to flow from the crest, violent explosions continued at the summit crater and the high-level craters of the south-western flank. In many of the explosions large blocks were thrown to a height of 500-600 m., and the detonations were so loud that it was difficult to sleep in Thorsadalur, $20 \mathrm{~km}$. distant from the volcano. Again, at shorter distances, the same explosions did not seem to be so loud owing to some acoustical trick.

Flashing arcs of light were a common sight. Ash was only occasionally blown out in quantity and was harmless at first. Nevertheless, if it continued into the haymaking period serious effects would follow. The pumice fall in Fljotshlidh and Eyjafjöll, however, caused the evacuation of some farms.

With the exception of the initial shock, notable earthquakes have not occurred in the vicinity of the volcano; but in the district of olfus very heavy shocks occurred on May 19. Hot-spring activity was greatly augmented, and every quiescent pool in a long, narrow strip of country became a violent geyser of dirty water.

In a further letter (July 17), Dr. Einarsson states that the eruption goes on. Lava still flows uninterruptedly (presumably from the south-west craters) without any noticeable decrease of volume. The eruption of ash, however, has diminished to jnsignificant proportions, and is doing no harm. A curious result is that "during one period of heavy ash fall and dry weather the sheep got the usual "eruption disease', which is caused by fluorine, but when a rainy period set in they somewhat recovered. The disease is, so far, not very serious."

With regard to the magnitude of the eruption, Dr. Einarsson is of opinion that the present eruption is at least as great as that of 1845 , and will probably prove ultimately to be greater.

I visited Copenhagen on a lecture tour during October, and gained a few further details from Prof. A. Noe-Nygaard, and saw his very fine film of the eruption. The new crater on the summit is $300-400 \mathrm{~m}$. in diameter, and has reached a height of $100 \mathrm{~m}$. The orifice which continues to emit lava at the southwestern end of the ridge is a fissure with six or seven small craters, very clearly seen in the film. The line along which the new eruption has taken place is situated some distance to the west of the still visible rent from which the eruption of 1845 was emitted. The film shows the minute details of the over-rolling and incorporation of solid lava-blocks by the liquid lava, and of auto-intrusion.

The accompanying map is re-drawn from a map published in the newspaper Morgunbladid (April 15, 1947) by Kjartansson, Hannesson and Thorarinsson. It shows the extent of the new flows (solid black) with additions (hatched) up to May 20. The very fine photograph of the eruption was taken by $V$. Sigurgeirsson of Reykjavik on the morning of March 29, the first day of the eruption, looking south-south-west.
Addendum. In a recent letter (November 9), Dr. Einarsson states that lava is still flowing in un. diminished quantity from the crater on the south. west. Explosive activity ceased at the end of June. The lava is becoming very rich in gases and is more fluid than before, while the temperature remains constant.

\section{CORN (ZEA MAYS L.) GENETICS IN THE UNITED STATES}

\section{BY GORDON HASKELL}

Connecticut Agricultural Experiment Station, New Haven, Connecticut

$M^{A}$ AIZE (Zea Mays L.), or 'corn' as it is known throughout North America and so called throughout this article, is by far the largest crop grown in the United States, having many different uses ranging from animal food, a basis for the manu. facture of nylon, to its use as table sweet corn. It is therefore not surprising that much time and money are spent investigating the corn plant. In addition to its economic importance, corn possesses a number of properties making it useful experimental material for cytologists, geneticists, plant breeders, and for evolutionists interested in the origins of cultivated plants. Some aspects of the genetic and breeding problems now attracting attention and an indication of lines of approach for solving them will give a brief indication of current work with this plant in the United States.

The problem drawing very wide attention at the moment is how to estimate combining ability of inbreds used in the production of hybrid seed corn. Modern strains of corn used commercially throughout the United States are known as 'double crosses' derived from crossing four inbred pure lines thus : $(A \times$ $B) \times(B \times C)$. It is therefore highly important to know what open-pollinated varieties still in existence are more likely on inbreeding to give rise to inbreds which have the ability to produce the largest amount of hybrid vigour when crossed with other inbred lines. Jones, Singleton, Nelson and Hayes believe that it is best first to obtain the inbreds themselves possessing good plant characters before determining their potency in various combinations with other inbred lines, their principal argument being that it is no use having excellent hybrids if the inbreds which go into them are difficult to keep going from year to year. This is very important for the seedsmen. On the other hand, Jenkins, G. F. Sprague and colleagues at Iowa State College advocate early testing, that is, to determine the potency of different lines before inbreeding. General combining ability defined as the average performance of a line in hybrid combinations, and specific combining ability with a standard tester line, may both be used as pre-testers before com. mencing the inbreeding programme. Early elimina. tion of varieties which pre-testing indicates will not produce inbreds possessing good combining powers, and selecting only the upper range, saves much labour inbreeding potentially unproductive material. The disadvantages of this method are, however, that testing requires a large amount of land and that open pollinated lines of corn are so heterozygous that often inbreeding has a drastic effect. There is no stability of the numerous genes segregating until after several 